\title{
Total Petroleum Hydrocarbon Content (TPH) As an Index Assessment of Macrophytic Remediation process of a Crude Oil Contaminated Soil Environment.
}

\section{EDWIN-WOSU, N. L.; ALBERT, E.}

\author{
Department of Plant Science and Biotechnology \\ University of Port Harcourt, P. M. B. 5323, Choba, \\ Rivers State, Nigeria.E-mail: edy2000_ecoland@yahoo.co.uk
}

\begin{abstract}
A short-term ecological study was carried out to comparatively evaluate the phytoremediation potential potential of two leguminous plant species. This aimed at quantifying residual TPH as index for assessing a post-phytoremediated crude oil contaminated soil. Plant and soil analysis were carried out using the photometric method of American Petroleum Institute (API). Result has shown that Leucaena leucocephala treated soil at various $(0,25,50, \& 100 \mathrm{mls})$ levels of pollution had TPH $(\mathrm{mg} / \mathrm{kg})$ content of $75.33 \pm 38.42,151.00 \pm 94.00,169.33 \pm 102.20$ and $196.00 \pm 115.00$ while Bauhinia monandra soil recorded 92.00 $\pm 12.00,166.00 \pm 82.30,276.00 \pm 51.20$, $391.00 \pm 143.20$. The soil TPH value is also in relation to the quantity accumulated in the species, which has shown $L$. leucocephala with higher level and low soil level and vice versa in B. monandra. This apparently indicated that both species could be applied in a phytoremediation exercise. Leucaena leucocephala tend to have more sustained potential for hydrocarbon accumulation and could be evaluated for its efficacy as a tool in phytoremediation exercise for cleaning up hydrocarbon contaminated soil. Thus could be good prospect in remediation environmental quality programme.@JASEM
\end{abstract}

Hydrocarbon is a family of organic compounds or a class of organic chemicals composed entirely of carbon and hydrogen atoms, which bond together as structure of the compound. It is considered to be an organic compound of simplest composition and may be thought to be the parent substance from which other compounds are derived (Sally and Mc Donald, 2002). Petroleum hydrocarbons are naturally occurring chemicals known to be the major component of crude oil and petroleum product (Britton 1984) used for a variety of activities, such as fueling of vehicles, machines and domestic usage, and their presence in the environment above regulatory consent limits indicate pollution.

Oil pollution has a large-scale negative impact on the terrestrial environment ranging from aesthetic quality modification to death of sensitive biotic species. The impact of oil spillage on the environment is most often assessed from changes in the physical, chemical and biological components of the ecosystem. The impact on the soil environment depends largely on the relative conditions of the soil and residual oil remains. A post oil spill THC analysis from the soil is required as part of monitoring and remediation programme. In today's era of heightened environmental awareness and good stewardship of limited natural resources effort to clean up contaminated sites involve series of remedial techniques or approaches ranging from conventional physicochemical techniques and natural attenuation to phytoremediation the most emerging biotechnology approach. Series of phytoremediation technology have been implemented or/ and are still going on in pilot and field scale organic and inorganic contaminated site. Different species of plants including grasses, leguminous and nonleguminous vascular plants, aquatic plants and

\footnotetext{
* Corresponding author: Edwin-Wosu, N. L.
}

hyperaccumulators have been involved in such application. But neither of such application may have been reported on Leucaena leucocephala and Bauhinia monandra. Therefore this study is aimed at determining their THC levels and in the postphytoremediated crude oil polluted soils as a demonstrative index to evaluate the efficacy of phytoremediation as a tool for cleaning up hydrocarbon contaminated soils.

\section{MATERIALS AND METHOD}

Experimental design: The nested completely randomized experimental design (Akindele 1996) was adopted, in which analysis of variance was carried out in a comparative study of two plant species for the remediation of a crude oil polluted soil. In such design Leucaena leucocephala and Bauhinia, monandra were involved in the application for four different simulated doses or levels $(0$, 25,50 and $100 \mathrm{mls}$ ) of crude oil polluted soil macroplot that were run in 10 replicates respectively.

Source of material: The crude oil was obtained from Shell Petroleum Development Company (SPDC), Port Harcourt. The two plant species of interest (Leucaena leucocephala and Bauhinia monandra) were obtained from the Rivers State Agricultural Development Programme (ADP) Farm Rumuodamanya from where the micro plot poly bags were also obtained and the premises of the University of Port Harcourt respectively.

Germination test: The approach adapted by Agboola (1998) was carried out using 50 randomly selected whole seeds of each of the two species. The seeds were the surface sterilized with $0.1 \%$ mercuric 
chloride solution for 30 seconds and rinsed in several changes of distilled water. Each had five replicates and each replicate had 10 seeds plated on the petri dishes. Lined with two moist filter papers each. The germination was monitored for seven days at room temperature of about $25^{\circ} \mathrm{c}$ and seeds were deemed to have germinated when radicle emergence reached $1 \mathrm{~cm}$.

Experimental pollution and post- pollution habitat reclamation treatment: From the proposed botanic garden of University of Port Harcourt topsoil was collected in bulk from $0-15 \mathrm{~cm}$ soil layers into large plastic bucket and conveyed to the greenhouse where polybags $\left(25 \mathrm{~cm}^{3}\right)$ were filled in replicate of treatment and control. The study sites (micro plots of loam soil replicates) with surface area $78.5 \mathrm{~cm}^{2}$ were polluted in doses of crude oil using the measuring cylinder. The levels of doses (mills) per $78.5 \mathrm{~cm}^{2}$ were $0,25,50$, and 100. Following 7 days post - pollution, the plant species were used as treatment options for the different pollution levels per micro plot,. Healthy 7day-old seedlings of the two species were planted into the control and polluted soil in the poly bags. The post phytoapplication ecological study was carried out for over a period of 16 weeks. Post pollution residual hydrocarbon was quantified by means of comparative analysis of the hydrocarbon content in the species and the treated soil by adopting the photometric method of the American Petroleum Institute (API) (1980).

Table 1: Pre and Post Pollution Hydrocarbon Concentration of the Treated Soil

\begin{tabular}{ccccc} 
& & \multicolumn{3}{c}{ Post pollution levels } \\
Conc. & Before pollution & 25 & 50 & 100 \\
$(\mathrm{mg} / \mathrm{kg})$ & $95.00 \pm 11.21$ & $400.00 \pm 181.40$ & $562.00 \pm 256.00$ & $562.00 \pm 256.00$ \\
& & & & \\
\hline
\end{tabular}

Table- 2: Post-Phytoapplication THC Concentration of Species and Treated Soils

\begin{tabular}{|c|c|c|c|c|}
\hline Pollution levels(mls) & Leucaena leucocephala (Ll) & Ll Soil & Bauhinia monandra(Bm) & $B m$ Soil \\
\hline Control & $41.00 \pm 13.20$ & $75.33 \pm 38.42$ & $35.33 \pm 3.00$ & $92.00 \pm 12.00$ \\
\hline 25 & $92.01 \pm 20.00$ & $151.00 \pm 94.00$ & $67.00 \pm 22.24$ & $166.00 \pm 82.30$ \\
\hline 50 & $85.00 \pm 17.00$ & $169.33 \pm 102.20$ & $51.00 \pm 15.20$ & $276.00 \pm 51.20$ \\
\hline
\end{tabular}

\section{RESULTS AND DISCUSSION}

The quantification of residual total hydrocarbon as shown in Table I indicates that the soil habitat before pollution had TPH concentration of $94.67 \pm 11.21 \mathrm{mg} / \mathrm{kg}(1.0 \%)$ and at different levels of seven days pollution, it has a simulation conc. of $400.00 \pm 181.40, \quad 562.00 \pm 256.00 \quad$ and $562.00 \pm 256.00 \mathrm{mg} / \mathrm{kg}$ at 25.50 and $100 \mathrm{mls}$ pollution level

The residual total as in Table II has shown different concentration of TPH in the remediating options. At the various levels $(0,25,50,100 \mathrm{mls})$ of pollution, Leucaena leucocephala had a concentration $(\mathrm{mg} / \mathrm{kg})$ of $41.00 \pm 13.20(0.41 \%), \quad 92.01 \pm 20.00, \quad(0.92 \%)$, $85.00 \pm 17.02(0.85 \%)$ and $75.33 \pm 18.04 \quad(0.75 \%)$, while Bauhinia monandra had $35.33 \pm 3.00(0.35 \%)$, $67.00 \pm 22.24 \quad(0.67 \%), \quad 51.00 \pm 15.20 \quad(0.51 \%)$, $46.00 \pm 14.00(0.46 \%)$.

The residual total hydrocarbon of the treated soil shows that L. leucocephala treated soil had a residual concentration of $75.33 \pm 38.42(0.75 \%), 151.00 \pm$ $94.00(1.51 \%), \quad 169.33 \pm 102.20(1.69 \%)$ and $196.00 \pm 115.00(1.96 \%)$ while $B$. monandra treated soil recorded a concentration $(\mathrm{mg} / \mathrm{kg})$ of $92.00 \pm 12.00$
$(0.92 \%), \quad 166.00 \pm 82.30 \quad(1.70 \%), \quad 276.00 \pm 51.20$ $(2.80 \%)$ and $391.00 \pm 143.20(3.91 \%)$ in the respective pollution levels. On a general note the result has shown a promising potential of Leucaena leucocephala for phytoremediation exercise.

As could be observed in the Tables- 1 and 2 it would be pertinent to assert that particular plant species appear to enhance remediation of oil - contaminated soil to some extent than other species. Also such result indicates that the apparent biodegradable capabilities show how natural biological process by anthropogenic response can be used to minimize environmental contamination. Leucaena leucocephala recorded some levels of performance in terms of enhanced TPH uptake from the treated soil than the Bauhinia monandra treated soil. This could be due to leaf droppings, adequate aeration and nodulation by the plants roots, thus implicative of it nitrogen fixing potential negating the ill-potential effect in B. monandra, (Edwin-wosu and Kinako, 2005)

The hydrocarbon levels varied within and between the species used as treatment options. Studies on $L$. leucocephala had indicated at the first instance a

* Corresponding author: Edwin-Wosu, N. L. 
considerable high-level hydrocarbon, which decreases as the experiment progresses with time. Bauhinia monandra had similar concentration decrease with time. Both species treated soil had initial increase followed by decrease. Leuccaena leucocephala had a pronounced reduction in concentration than B. monandra, which is shown in degradation indicating that there could still have been minimal or no microsymbiotic activity in the plant. But this may have taken place in the L. leucocephala microbial soil environment, which could enhance crude oil uptake by this plant through time of the experiment and subsequently deplete hydrocarbon level of the soil.

Similarly several studies have identified various plants for their potential to facilitate the phytoremediation of sites contaminated with petroleum hydrocarbons. In the majority of studies grasses and legumes have been single out for their potential in this report. April and Sims (1990) established a mix of eight Prairie grasses on sandy loam soils to determine whether the degradation of four PAHs (benzo (a) pyrene, benzo (a) anthracene, dibenzo (a, h) anthracene, and chrysene) was stimulated by plant growth. The eight grasses included: Big bluestem, Little bluestem, Indian grass, switch grass, Canada wild rye, side oats grama, blue grama and Western wheat grass. The extent of PAH disappearance was consistently greater in planted units compared to it's removal in unplanted control indicating that phytoremediation enhanced the removal of these compounds from contaminated the soil.

Result of an investigation by Reilley et al (1996) indicates that grasses and legumes enhanced the removal of PAHs from contaminated soils. The plant (investigated independently) included the legume alfalfa and three grasses: tall fescue, Sudangrass and switchgrass. Pyrene and anthrecene were used as PAH contaminants. Planted soils had significantly lower concentration of PAHs than the unplanted soils, with 30 to $40 \%$ more degradation in the planted soils and this as been noted could be due to enhanced rhizosphere effect.

Reynolds and Wolf (1999) examined the phytoremediation potential of two cold - hardy plants, Arctared red fescure and annual typegrass, planted together in soil contaminated with either crude oil or diesel. Result of the experiment indicated that contaminated soils planted with the two species had significantly lower concentrations of total petroleum hydrocarbon (TPH) compare to unplanted controls. The initial crude oil concentration for planted treatments and an unplanted control was approximately $6200 \mathrm{mg} \mathrm{TPH}$ per $\mathrm{kg}$ soil, while the initial diesel concentration was approximately $8350 \mathrm{mg}$ TPH per kg. After 640 days, crude oil contaminated soil planted with both species had $1400 \mathrm{mg}$ TPH per $\mathrm{kg}$ soil (77\% reduction), while the unplanted control contained $2500 \mathrm{mg}$ TPH per hg soil (60\% reduction). Similar diesel. Contaminated soil planted with both species had 700mg TPH per kg soil (92\% reduction) after 640 days compared to $2200 \mathrm{mg}$ $\mathrm{TPH}$ per $\mathrm{kg}$ soil (74\% reduction) for the unplanted control.

Furthermore, in a six-month laboratory study, Pradhan et al, (1998) have identified that alfalfa, switchgrass, and little bluestem were each capable of reducing the concentration of PAHs in soil contaminated at a manufactured gas plant. The initial soil concentration of total PAHs for the three plant treatments and an unplanted control was $184.50 \pm 14.00 \mathrm{mg}$ total PAHs per $\mathrm{kg}$ of soil. After six months, the concentration in unplanted control, soil was $135.90 \pm 25.50 \mathrm{mgkg}^{-1}$, while the concentrations in planted treatment were (switch grass = $79.50 \pm 3.70 \mathrm{mgkg}^{-1}$, alfalfa $=80.20 \pm 8.90 \mathrm{mgkg}^{-1}$, little bluestem $=97.10 \pm 18.70 \mathrm{mgkg}^{-1}$ ).

Related studies have shown that spilled oil degradation is rapidly accelerated in vegetated soils than surrounding non-vegetated bulk soils (Witse et al, 1998, Banks et al, 2000). Low concentrations of low molecular weight polynuclear aromatic hydrocarbon (PAH) were detected in root peel of Daucus carota (Wild and Jones, 1992). Also reported was an enhanced mineralization of PCBs by crested wheat grass (Agropyron desertorium and accelerated removal of PAHs, TCE, and TNT by Prairie grasses (Foth 1990; Wolfe et al, 1993). Schawb et al, (1995) have reported on the mineralization of phenanthrene from soil planted to Sorghum, Bermuda grass, or alfalfa. Results of 14-day study indicated significantly higher mineralization of $\left({ }^{14} \mathrm{c}\right)$ phenanthrene by the two warm - season grasses sorghum $\left(0.46 \%\right.$ of recovered $\left.{ }^{14} \mathrm{c}\right)$ and Bermuda grass $(0.31 \%)$-compared to a sterile, unplanted control $(0.11 \%)$. There was no significant difference between mineralization of phenanthrene in soil planted to alfalfa $(0.09 \%)$ and the control.

Finally, in a survey of 15-oil - contaminated sites in Western Europe, Gudin and Syratt (1975) found several types of legumes growing abundantly in oil contaminated areas. These plants included alfalfa, white clover, birdsfoot trefoil, black medick as well as Psoralea bituminosa, Robinia pseudacacia, Malilotus altissima and Vicia tetrasperma.

\section{REFERENCE}

Agboola, D A (1998). Dormancy and seed germination in some weeds of tropical waste lands. Nigerian Journals Botany 11: 79-87

\footnotetext{
* Corresponding author: Edwin-Wosu, N. L.
} 
Akindele, S O (1996). Basic experimental Design in Agricultural Research. Federal University of Technology Akure, ( FUTA)Nigeria

API (1980). Manual on disposal of petroleum wastes. American Petroleum Institute, Washington D. C.

Aprill, W; Sims, R C (1990). Evaluation of the use of prairie grasses for stimulating polycyclic aromatic hydrocarbon treatment in soil. Chemosphere 20(1-2): 253-265.

Banks, M K; Govindaraju, R S; Schwab, A P; Kulakow, P (2005). Part 1: field Demonstration, In: phytoremediation of hydrocarbon contaminated soil, S. Florenza, C. L. Oubre and C.H. Ward (eds.) pp 3 - 88, Baton Ronge, L. A. Lewis Publishers.

Britton, L. N. (1984). Microbial degradation of Aliphatic hydrocarbons In: microbial degradation of Organic compounds. Microbiology series: volume 13. Marcel Dekker Inc. New York.

Edwin-wosu, N L; Kinako, P D S (2005). Phytoremediation (series 2): a short-term comparative analysis of enhanced biodegradation of crude oil in the soil by macrophytic nodulation Global Journal Environmental Science. 4 (1): 11-18

Foth, H D (1990). Fundamentals of soil science. New York Wiley $8^{\text {th }} \mathrm{Ed}$.

Gudin, C; Syratt, W J (1975). Biological aspects of land rehabilitation following hydrocarbon contamination. Environmental pollution 8: 107112

Padhan, S P; Conrad, J R; Paterek, J R; and Srivastava V J (1998). Potential of phytoremediation for treatment of PAHs in soil at MGP sites. Journal of soil contamination. 7(4): 467- 480.

Reilley, K A; Banks, M K; Schwab, A P (1996). Organoc chemicals in the environment: dissipation of Policyclic aromatic hydrocarbons in the rhizosphere. Journals of Environmental Quality 25:212-219.
Reynolds, C M; Wolf, D C (1999). Microbial based strategies. For assessing rhizosphere - enhanced phytoremediation. Proceedings of the phytoremediation technical seminar-May 31June 1, 1999. Calgary. A. B. Environment Canada Ottawa pp 125 - 135

Sally, G and McDonald, N (2002). Bioremediation: an innovative solution for soil contamination. A final report submitted to the 2002 Aventis Biotech, challenge competition Halifax, Nova Scotia pp $-1-18$

Schnoor, J L (1997). Design of phytoremediation at contaminated sites. Ground water remediation and technologies analyses Center. Presentations: Advances in Innovative Groundwater Remediation Technologies Philadelphia, P. A. July 311997.

Schwab, A P; Banks, M K; Arunachalam, M (1995). Biodegradation of polycyclic aromatic hydrocarbons of rhisosphere soil. In; Bioremediation of Recalcitrant Organics. R. E. Hinches, D. B. Anderson, and R. E. Hoeppel. Battelle Press: Columbus pp 23-229

Steve, R; Daniel, P (1996). Bioremediation of hazardous waste sites. Phytoremediation, practical approach to implementation US EPA. Cincinnatic-OH. Dynamic Co-operation, Ada Ok.

Wild, S R; Jones, K C (1992). Polyaromatic hydrocarbon uptake by carrots grown in sludge amended soil. Journal of Environmental Quality. 21: 217-225.

Wiltse, C C; Rooney, W L; Chen, A; Schwab, A P; Banks, M K (1998). Greenhouse evaluation of agronomic and crude oil phytoremediation potential among alfalfa genotypes. Journal of Environmental Quality. 27: 169-173.

Wolfe, N L; Ou, T Y; Carreira, L (1993). Biochemical remediation of TNT contaminated soil Rep. US. Army Corps. Eng. 